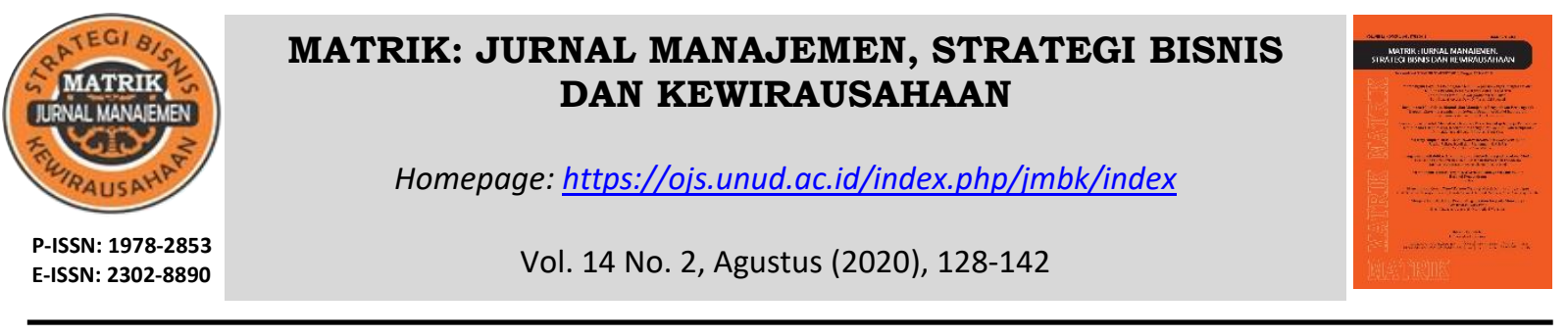

\title{
Anak-anak dan Advergame: Pengaruh Pengalaman Flow dan Persuasion Knowledge pada Sikap dan Niat Pembelian
}

\author{
Santirianingrum Soebandhi ${ }^{1)^{*}}$,Sri Hartini ${ }^{2)}$, Sri Gunawan ${ }^{3)}$ \\ ${ }^{1}$ Universitas Wijaya Kusuma Surabaya, \\ ${ }^{2,3}$ Universitas Airlangga Surabaya \\ email: santirianingrum@uwks.ac.id
}

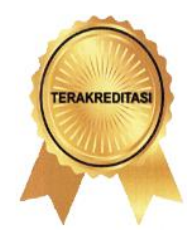

SINTA 2

DOI : : https://doi.org/10.24843/MATRIK:JMBK.2020.v14.i02.p01

\begin{abstract}
ABSTRAK
Bermain video game telah menjadi aktivitas yang disukai anak-anak. Salah satu upaya pemasaran untuk menarik perhatian mereka adalah dengan mengombinasikan iklan dan hiburan dalam bentuk advergame atau advertising game. Dengan semakin meningkatnya penggunakan advergame terutama yang ditujukan pada anak-anak, penelitian ini bertujuan untuk menganalisis efektifitas advergame melalui pengalaman flow dan persuasion knowledge terhadap advergame dan brand attitude serta niat beli mereka terhadap produk yang melekat dalam game. Penelitian ini melibatkan 218 anak-anak usia 10-12 tahun di Jakarta dan Surabaya. Tujuh hipotesis diajukan untuk dinalisis lebih lanjut. Berbeda dengan studi-studi sebelumnya, hasil menunjukkan bahwa sikap atas advergame tidak berpengaruh pada niat anak-anak untuk membeli produk yang diiklankan. Temuan penelitian ini menawarkan beberapa implikasi, batasan dan arahan untuk penelitian selanjutnya.
\end{abstract}

Kata kunci: persuasion knowledge, advergame attitude, brand attitude, purchase intention

\section{Children and Advergame: The Impacts of Flow Experience and Persuasion Knowledge on Attitudes and Purchase Intention}

\begin{abstract}
Playing a video game has become a favorite activity for children. One of the marketing efforts to attract their attention is by combining advertising and entertainment in the form of advergame or advertising game. Childhood is considered as a critical period towards the impact of advertising. As more advergame played especially intended for children, this study aims to analyze the effectiveness of advergame through flow experience and persuasion knowledge towards advergame and brand attitude as well as their purchase intention towards the embedded product in the game. This study was participated by 218 children aged 10-12 years old in Jakarta and Surabaya. Seven hypotheses were proposed to be analyzed further. Different from the previous studies, this study shows that attitudes on advergame do not influence the children intention to purchase the advertised product. The findings also offer some implications, limitations and directions to the future research.
\end{abstract}

Keyword: persuasion knowledge, advergame attitude, brand attitude, purchase intention

\section{PENDAHULUAN}

Internet telah menyebabkan banyak perubahan termasuk di sektor periklanan. Secara global, media pemasaran seperti Internet dan video game advertising menunjukkan kecenderungan untuk tumbuh (Redwing, 2014). Di Indonesia, walaupun televisi masih merupakan media iklan utama, akan tetapi iklan berbasis Internet menunjukkan pertumbuhan pesat dibandingkan media-media lainnya (PwC, 2017). Internet juga mengakibatkan semakin 
beragamnya media yang digunakan anak-anak (Rideout, Foehr, \& Roberts, 2010). Jika sebelumnya mereka hanya mengenal televisi, radio, dan majalah, saat ini mereka semakin familier dengan Internet, PC, dan telepon genggam (Hendriyani, Hollander, D'Haenens, \& Beentjes, 2012). Mereka juga semakin familiar dengan media digital dan menghabiskan banyak waktu dalam lingkungan multimedia (Moore \& Rideout, 2007; Waiguny, Terlutter, \& Zaglia, 2011). Sebagai akibatnya anak-anak dihadapkan dengan semakin meningkatnya jumlah pesan iklan melalui media yang sangat beragam (Verhellen, Oates, Pelsmacker, \& Dens, 2014). Mengingat bahwa anak-anak usia dibawah 15 tahun mencapai 28,87\% dari 237,6 juta jumlah penduduk Indonesia (BPS, 2010, 2011), tidak mengherankan jika anak-anak dianggap sebagai pasar potensial yang penting oleh industri media (Buckingham, 2000; Calvert, 2008).

Untuk dapat menarik perhatian anak-anak, pemasar dituntut kreatif dalam mempromosikan produknya. Alternatif yang semakin diminati adalah dengan mengombinasikan advertising dengan digital game (Mackay, Ewing, Newton, \& Windisch, 2009; Nicovich, 2005; Steffen, Mau, \& Schramm-klein, 2013) atau advergame. Dalam advergame, merek atau produk merupakan sentral dari game sehingga pesan yang disampaikan menyatu dalam pengalaman bermain game (Cauberghe \& Pelsmacker, 2010). Penggunaan advergame pada anak-anak umumnya ditujukan agar mereka dapat belajar tentang produk dan perusahaan (Bogost, 2007) dan sebagai hasilnya diharapkan dapat membentuk sikap positif terhadap merek (Waiguny, Nelson, \& Terlutter, 2012).

Sikap dapat terbentuk dari pengalaman flow yang dirasakan ketika memainkan advergame. Flow merupakan keadaan dimana seseorang benar-benar terlibat dalam aktivitas yang sedang dilakukan sehingga ia lupa waktu dan lupa akan aktivitas-aktivitas lain yang tidak berhubungan dengan aktivitas yang sedang dilakukan pada saat itu (Csikszentmihalyi, 1990; Hoffman \& Novak, 2009). Seseorang yang berada dalalam kondisi flow akan semakin mudah dipersuasi karena ia akan cenderung menerima pesan atau saran yang disampaikan (Hoffman \& Novak, 2009). Semakin tinggi flow yang dirasakan, semakin tinggi motivasi untuk memainkan game dan dapat membuat anak-anak ingin memainkannya kembali. Dengan semakin meningkatnya paparan advergame, efek persuasi dari game juga meningkat (Jin, 2011; Waiguny, 2013).

Penelitian terdahulu terkait dengan pengaruh flow terhadap sikap dan niat beli menunjukkan hasil yang beragam. Beberapa penelitian menunjukkan bahwa flow memiliki dampak positif pada sikap dan permintaan responden pada merek yang diiklankan (misal: Bellman, Kemp, Haddad, dan Varan (2014), Gurău (2008), Steffen et al. (2013)). Sedangkan penelitian-penelitian lain menunjukkan hasil yang bebeda (Mau, Silberer, dan Constien (2008); Soebandhi, Hartini, dan Gunawan (2018); 2020)

Selain flow yang merupakan aspek afeksi, aspek kognisi juga merupakan komponen penting pembentuk sikap (Baker, 2010; Breckler \& Wiggins, 1989). Ketika pemasar mempengaruhi konsumen melalui iklan, pada saat yang bersamaan konsumen juga akan mengintepretasikan dan mengatasi taktik yang dilakukan pemasar. Konsumen akan mengembangkan pengetahuan tentang persuasi. Menyadari usaha pemasar dan mengevaluasi pesan dengan menggunakan persuasion knowledge (PK) akan membantu konsumen untuk memutuskan secara lebih sadar dan dapat menyebabkan perubahan efek persuasi terhadap sikap dan perilaku (Friestad \& Wright, 1994, 1999). Waiguny dan Terlutter (2010) mengemukakan jika anak-anak menyadari bahwa advergame merupakan sarana promosi, mereka akan memiliki pengalaman yang kurang menyenangkan dan dapat meningkatkan keraguan terhadap advergame. Kekuatan PK sebagai pertahanan terhadap pengaruh advergame bergantung pada kapasitas kognisi yang dimiliki oleh konsumen yang menjadi target (Campbell \& Kirmani, 2000). Jika sumber daya kognisi ini tersedia, maka mereka akan membentuk sikap skeptis dan dapat menghasilkan evaluasi negatif terhadap advergame 
maupun merek yang diiklankan (Bousch, Friestad, \& Wright, 2009; Robertson \& Rossiter, 1974; Waiguny \& Terlutter, 2010).

Walaupun PK diyakini dapat berdampak negatif pada evaluasi anak-anak pada merek yang melekat dalam game, akan tetapi penelitian Mallinckrodt dan Mizerski (2007) pada anakanak usia 5-8 tahun menunjukkan bahwa meningkatnya PK tidak berpengaruh pada preferensi merek atau niat untuk meminta produk Froot Loops setelah memainkan advergame. Bahkan pada kelompok anak usia yang lebih tua ( \pm 8 tahun), semakin mereka mengetahui maksud persuasi dari advergame tersebut, semakin tinggi preferensi mereka terhadap merek yang diiklankan. Sebaliknya, penelitian Soebandhi et al. (2018) pengaruh negatif PK hanya ditunjukkan terhadap merek yang diiklankan akan tetapi tidak berpengaruh pada sikap anakanak atas advergame. Hal ini menunjukkan bahwa PK belum tentu berlaku pada konteks advergame (Evans \& Park, 2015). Adanya perbedaan hasil terkait PK dalam konteks digital ini membuat penelitian lebih lanjut terkait PK terutama dalam konteks advergame pada anak-anak penting dilakukan untuk menganalisis efektifitas dari advergame.

Dengan semakin meningkatnya penggunaan advergame terutama yang ditujukan pada anak-anak dan oleh karena mereka merupakan usia yang rentan pada pengaruh iklan, maka penelitian ini bertujuan untuk menganalisis efek dari memainkan advergame terhadap sikap dan niat mereka untuk melakukan pembelian melalui pengalaman flow dan persuasion knowledge.

Advergame merupakan perpaduan antara iklan dan hiburan yang berbentuk video game dan sengaja dirancang untuk mempromosikan merek atau produk perusahaan (Gross, 2010; Terlutter \& Capella, 2013; Youn \& Mira, 2012) (Obringer, 2007). Dalam advergame karakter produk, logo dan pesan iklan ditampilkan menyatu dalam game (Mallinckrodt \& Mizerski, 2007). Kelebihan advergame dibandingkan televisi atau radio adalah pemain dapat berinteraksi dengan merek atau produk secara virtual, dapat menarik perhatian karena dapat dimainkan berulang kali, serta dapat didistribusikan dengan cepat dan mudah (Gurău, 2008; Solomon, 2018; Waiguny et al., 2011). Oleh karena advergame umumnya terdapat di website merek, pemain sudah menyadari merek apa yang ada dalam advergame tersebut bahkan sebelum mereka memainkannya. Sehingga untuk menilai efektivitas dari advergame lebih tepat jika menggunakan sikap terhadap merek maupun pilihan produk daripada brand recall (Youn \& Mira, 2012).

Flow merupakan suatu keadaan dimana pemain begitu larut dalam aktivitas yang dilakukannya dan tidak memperhatikan hal-hal lain selain aktivitas tersebut (Csikszentmihalyi, 1990; Csikszentmihalyi \& Lefevre, 1989; Hoffman \& Novak, 2009). Efek dari pengalaman menyenangkan ini dapat memiliki dampak positif pada advergame maupun pada merek yang diiklankan. Flow state dicirikan oleh perhatian yang terfokus pada game yang sedang dimainkan, lupa waktu dan tidak menyadari lingkungan sekitarnya (Nakamura \& Csikszentmihalyi, 2002; Sherry, 2004). Ketiganya penting untuk dapat mencapai luaran game yaitu respon afeksi yang positif (Chen, 2006).

Ketika memainkan game, anak-anak akan fokus untuk memenangkan permainan. Hal ini menghabiskan sumber daya kognitif mereka sehingga mereka cenderung tidak memperhatikan hal-hal lain diluar game yang sedang dimainkan (Lang, 2000; Vermeir, Kazakova, Tessitore, Cauberghe, \& Slabbinck, 2014). Hal ini dapat menguntungkan pemasar, karena anak-anak tidak menyadari bahwa advergame sebenarnya adalah iklan sehingga mereka bisa menerima advergame dan merek yang diiklankan (Hernandez, 2011; Lu, Baranowski, Thompson, \& Buday, 2012). Selanjutnya, hilangnya kesadaran diri dan lupa waktu membuat paparan advergame menjadi lebih lama sehingga pesan merek yang terintegrasi dalam game dapat dengan mudah diulang (Waiguny et al., 2012). Paparan berulang ini dapat meningkatkan efek 
persuasi pada anak-anak (Hang \& Auty, 2011). Berdasarkan penjelasan di atas, maka hipotesis dapat dirumuskan sebagai berikut:

$\mathrm{H}_{1}$ : Flow berpengaruh positif terhadap advergame attitude

$\mathrm{H}_{2}$ : Flow berpengaruh positif terhadap brand attitude

Informasi produk atau merek yang ada dalam advergame bersifat terselubung karena terintegrasi dalam game yang dimainkan. Hal ini membuat anak-anak sulit mengenali bahwa advergame merupakan salah satu strategi pemasaran yang bertujuan untuk mempengaruhi mereka. Tingkat dimana anak-anak memahami dan mengenali upaya pemasar ini bergantung pada persuasion knowledge (PK) yang mereka miliki. PK terbentuk seiring dengan berjalannya waktu. Pengetahuan ini membantu mereka mengenali, menganalisis, menafsirkan, mengevaluasi, dan berfungsi sebagai alat pertahanan terhadap upaya persuasi tersebut. Sebagai konsekuensi dari pembelajaran/pengalaman ini, sikap dan perilaku konsumen juga dapat berubah terhadap upaya yang dilakukan oleh pengiklan atau tenaga penjual (Friestad \& Wright, 1994).

Rozendaal, Lapierre, Reijmersdal, dan Buijzen (2011) mengemukakan bahwa respon anak-anak terhadap komunikasi pemasaran bergantung pada tingkat pemahaman mereka tentang praktik-praktik pemasaran. Mereka akan menggunakan pengetahuan tersebut sebagai pertahanan untuk melawan pengaruh iklan (Boerman, Reijmersdal, \& Neijens, 2013). Anakanak yang mengetahui siapa yang membuat advergame dan apa tujuan advergame itu dibuat akan cenderung bersikap ragu terhadap advergame maupun merek yang melekat didalamnya (An \& Stern, 2011; Verhellen et al., 2014). Semakin mereka mengetahui siapa dan untuk apa advergame itu dibuat (semakin tinggi persuasion knowledge) maka mereka akan membentuk evaluasi negatif baik terhadap advergame maupun merek yang terintegrasi dalam advergame (Friestad \& Wright, 1994, 1999; Wright, Friestad, \& Boush, 2005). Berdasarkan penjelasan diatas maka diajukan hipotesis sebagai berikut:

$\mathrm{H}_{3}$ : Persuasion knowledge berpengaruh negatif terhadap advergame attitude

$\mathrm{H}_{4}$ : Persuasion knowledge berpengaruh negatif terhadap brand attitude

Sikap (attitude) merupakan respon positif atau negatif seseorang terhadap suatu obyek dan berperan dalam keputusan pembeliannya (Ajzen, 2008). Sedangkan Hoyer, MacInnis, dan Pieters (2013) mendeskripsikan sikap sebagai evaluasi secara keseluruhan yang mengungkapkan rasa suka atau tidak suka seseorang terhadap suatu objek, masalah, orang, atau tindakan. Hal inilah yang menjadi alasan kenapa seseorang memiliki sikap terhadap merek, iklan, dan sebagainya.

Sikap atas iklan merupakan kecenderungan untuk merespon secara positif atau negatif atas stimulus iklan selama paparan tertentu (Lutz, 1985). Dalam hal advergame, sikap atas advergame mewakili konstruk afeksi yang merupakan kecenderungan penilaian positif atau negatif terhadap advergame yang diperoleh dari interaksi aktif antara pemain dan game (Hernandez, Chapa, Minor, Maldonado, \& Barranzuela, 2004). Sedangkan sikap atas merek merupakan evaluasi seseorang terhadap suatu merek berdasarkan keyakinan akan atribut yang dimiliki oleh merek tersebut (Mitchell \& Olson, 1981). Sikap juga merupakan kecenderungan seseorang untuk merespon terhadap suatu merek setelah adanya stimulus iklan (Phelps \& Hoy, 1996). Oleh karenanya, hipotesis dapat dirumuskan sebagai berikut:

$\mathrm{H}_{5}$ : Advergame attitude berpengaruh positif terhadap brand attitude

$\mathrm{H}_{6}$ : Advergame attitude berpengaruh positif terhadap purchase intention

Purchase intention menunjukkan kecenderungan seseorang untuk membeli merek atau produk tertentu. Niat ini umumnya didasarkan pada pencocokan antara motif pembelian 
dengan atribut atau karakteristik merek yang dipertimbangkan. Pembentukan niat melibatkan banyak proses termasuk didalamnya adalah pembentukan sikap (Belch \& Belch, 2018). Dengan kata lain, niat untuk membeli suatu produk memiliki rangkaian evaluasi sebelum ia memutuskan untuk membeli produk. Keputusan pembelian merupakan proses yang kompleks. Dalam pemasaran, purchase intention ini seringkali digunakan untuk memprediksi pembelian aktual (Kardes, Cronley, \& Cline, 2011). Hal ini dikarenakan konsumen dengan niat untuk membeli produk tertentu akan menunjukkan tingkat pembelian aktual yang lebih tinggi daripada konsumen yang menunjukkan bahwa mereka tidak memiliki niat untuk membeli (Voges, Pope, \& Brown, 2003). Adapun hipotesis yang diajukan adalah:

$\mathrm{H}_{7}$ : Brand attitude berpengaruh positif terhadap purchase intention

Kerangka konseptual yang diajukan dalam penelitian ini adalah sebagai berikut:

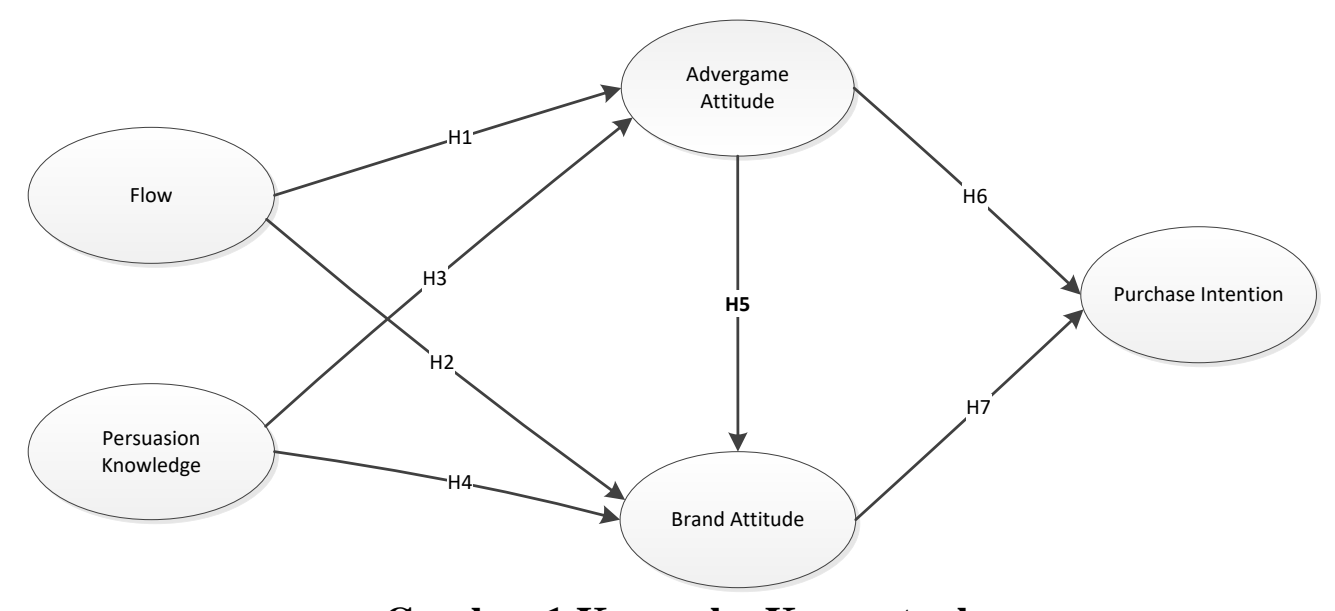

Gambar 1 Kerangka Konseptual

\section{METODE PENELITIAN}

Studi ini difokuskan pada anak-anak usia 10-12 tahun. Usia ini merupakan target pemasaran yang sangat menarik, karena mereka sedang dalam proses pembentukan identitas dan preferensi konsumen (Bahn, 1986; Kaneva, 2007). Pada usia ini mereka mulai dapat memahami tujuan iklan dan memiliki kemampuan untuk mempertimbangkan beberapa atribut merek dan dapat memberikan penilaian terhadap suatu produk atau merek (Gunter, 2016; John, 1999; Moore \& Rideout, 2007; Rozendaal, Buijzen, \& Valkenburg, 2009, 2010). Diusia ini mereka juga sudah memahami tujuan iklan dan dapat menggunakan pengetahuan tersebut untuk menolak pesan persuasif iklan, meskipun demikian mereka belum menggunakan pemahaman ini jika pesan iklan tidak ditampilkan secara eksplisit (Brucks, Armstrong, \& Goldberg, 1998; Moore \& Rideout, 2007).

Penelitian ini melibatkan 218 responden dari Jakarta dan Surabaya karena kedua kota ini memiliki jumlah pengguna Internet dan anak usia sekolah dasar terbanyak di pulau Jawa (Kemdikbud, 2018; Kominfo, 2013) sehingga dapat digunakan untuk memberikan gambaran profil pengguna Internet usia anak-anak. Convenience sampling digunakan untuk pengambilan sampel dan pengambilan data dilakukan di lingkungan sekolah masing-masing, Sebelum pengambilan data, diperlukan ijin dari pihak sekolah dan orang tua.

Oleh karena penelitian ini ditujukan untuk anak-anak, maka indikator yang digunakan untuk menjelaskan konstruk yang diteliti dibuat sederhana dan tidak banyak (Panic, Cauberghe, \& De Pelsmacker, 2013). Penelitian ini menggunakan $2-3$ indikator untuk setiap konstruk yang diteliti. Flow diukur melalui tiga item yang diadopsi dari Vanwesenbeeck, Ponnet, dan 
Walrave (2016). PK diukur dengan dua item yang dikembangkan oleh Panic et al. (2013). Advergame attitude diukur dengan tiga item yang diadopsi dari Hernandez (2008). Selanjutnya brand attitude dengan tiga item dari Roedder, Sternthal, dan Calder (1983). Terakhir purchase intention diukur dengan dua item yang diadopsi dari Rozendaal, Slot, Reijmersdal, dan Buijzen (2013). Pertanyaan-pertanyaan tersebut selanjutnya diterjemahkan dan disesuaikan untuk anak-anak di Indonesia.

Dalam penelitian ini digunakan empat poin skala Likert yang didesain dengan menggunakan emoji yang menarik bagi anak-anak (Hall, Hume, \& Tazzyman, 2016). Ekspresi yang tampak dalam ikon ini mulai dari ekspresi bahagia sampai dengan tidak bahagia (Reynolds-keefer \& Johnson, 2011) dengan pilihan jawaban Sangat Setuju - Sangat Tidak Setuju, sedangkan PK menggunakan pilihan jawaban Sangat Tahu - Sangat Tidak Tahu (Soebandhi et al., 2018, 2020). Anak-anak diminta memainkan advergame selama \pm 15 menit. Advergame yang digunakan merupakan advergame yang sengaja didesain dengan merek fiktif untuk menghindari familieritas terhadap game dan merek. Anak-anak dapat memainkan advergame melalui perangkat yang tersedia (mobile phone, tablet, laptop dan PC). Setelah memainkan advergame, mereka diminta untuk mengisi kuesioner dengan didampingi peneliti untuk membantu menjelaskan maksud pertanyaan kuesioner.

Kuesioner terdiri dari tiga bagian. Bagian pertama berisi narasi tentang game yang akan dimainkan dan makna dari masing-masing skala penelitian. Bagian kedua tentang deskripsi responden (yaitu: usia, jenis kelamin dan tempat tinggal). Bagian terakhir berisi pertanyaanpertanyaan kuesioner terkait dengan konstruk-konstruk yang diteliti. Selanjutnya data dianalisis dengan menggunakan metode Partial Least Square - Structural Equation Modeling (PLS-SEM) untuk memvalidasi hubungan antar variabel.

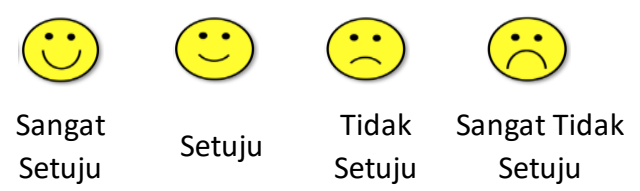

\section{Gambar 2 Skala Likert dengan menggunakan Smiley Icon}

\section{HASIL DAN PEMBAHASAN}

Hasil analisis deskriptif responden menunjukkan bahwa mayoritas responden berusia 11 tahun $(n=152 ; 69.72 \%)$. Responden terbanyak berdomisili di Surabaya $(n=116 ; 57.14 \%)$ kemudian diikuti oleh responden dengan domisili Jakarta $(n=102 ; 42.86 \%)$. Selanjutnya, jumlah responden perempuan dan laki-laki tidak menunjukkan perbedaan yang signifikan (perempuan: 50.46\%; laki-laki: 49.54\%).

Outer model digunakan untuk mengevaluasi hubungan antara indikator dan konstruknya. Hal ini dilakukan untuk memastikan bahwa indikator/instrumen survei yang digunakan dalam penelitian adalah valid dan dapat diandalkan. Dalam proses ini, tiga hal yang dievaluasi adalah composite reliability (CR), average variance extracted (AVE), dan factor loadings (Hair Jr, Sarstedt, Hopkins, \& G. Kuppelwieser, 2014).

Average Variance Extracted (AVE) dan Composite Reliability (CR) digunakan untuk mengukur convergent and discriminant validity. Berdasarkan Tabel 2, nilai AVE berada antara 0.5582 - 0.7563 lebih tinggi dari level yang dapat diterima yaitu 0.5. Sedangkan nilai CR berada antara 0.791 - 0.8621 lebih besar dari 0.7 yang berarti memiliki konsistensi internal yang bagus (Hair, Hult, Ringle, \& Sarstedt, 2014). 
Tabel 1 Profil Deskriptif Responden

\begin{tabular}{llll}
\hline Karakteristik & & Frekuensi & Persentase \\
\hline \multirow{4}{*}{ Usia } & 10 & 40 & $18.35 \%$ \\
& 11 & 152 & $69.72 \%$ \\
& 12 & 26 & $11.93 \%$ \\
Kota & Total & 218 & $100 \%$ \\
& Surabaya & 116 & $57.14 \%$ \\
& Jakarta & 102 & $42.86 \%$ \\
Jenis Kelamin & Total & 218 & $100 \%$ \\
& Goy & 110 & $50.46 \%$ \\
& Total & 108 & $49.54 \%$ \\
\hline
\end{tabular}

Tabel 2 Nilai AVE, Composite Reliability, and R square

\begin{tabular}{llll}
\hline & AVE & $\begin{array}{l}\text { Composite } \\
\text { Reliability }\end{array}$ & R Square \\
\hline Flow $\left(\mathrm{X}_{1}\right)$ & 0.6778 & 0.8621 & 0 \\
PK $\left(\mathrm{X}_{2}\right)$ & 0.7563 & 0.8612 & 0 \\
Adv. Att $\left(\mathrm{Y}_{1}\right)$ & 0.5582 & 0.791 & 0.0701 \\
Brand Att $\left(\mathrm{Y}_{2}\right)$ & 0.6309 & 0.836 & 0.2325 \\
PI $\left(\mathrm{Y}_{3}\right)$ & 0.6649 & 0.7953 & 0.2768 \\
\hline
\end{tabular}

Untuk mengkonfirmasi discriminant validity, cross loadings dari masing-masing indikator diukur, dan hasil menunjukkan bahwa seluruh cross loading setiap indikator terhadap konstruknya lebih besar dibandingkan dengan cross loading terhadap konstruk lainnya.

\section{Tabel 3 Cross Loading Indikator}

\begin{tabular}{llllll}
\hline & \multicolumn{1}{c}{ Flow } & \multicolumn{1}{c}{ PK } & Adv. Att & Brand Att & \multicolumn{1}{c}{ PI } \\
\hline X1.1 & $\mathbf{0 , 7 0 6 9}$ & $-0,1249$ & 0,0806 & 0,12 & 0,0619 \\
X1.2 & $\mathbf{0 , 8 5 3 7}$ & $-0,0578$ & 0,109 & 0,1518 & 0,098 \\
X1.3 & $\mathbf{0 , 8 9 7 2}$ & $-0,1611$ & 0,2025 & 0,2736 & 0,2639 \\
X2.1 & $-0,1077$ & $\mathbf{0 , 8 4 2 4}$ & $-0,1902$ & $-0,2135$ & $-0,294$ \\
X2.2 & $-0,1459$ & $\mathbf{0 , 8 9 6 2}$ & $-0,1932$ & $-0,2878$ & $-0,2869$ \\
Y1.1 & 0,1651 & $-0,2088$ & $\mathbf{0 , 7 1 6 1}$ & 0,3231 & 0,175 \\
Y1.2 & 0,147 & $-0,121$ & $\mathbf{0 , 7 3 5 1}$ & 0,2685 & 0,2698 \\
Y1.3 & 0,0857 & $-0,1602$ & $\mathbf{0 , 7 8 8 4}$ & 0,32 & 0,2241 \\
Y2.1 & 0,086 & $-0,1584$ & 0,3486 & $\mathbf{0 , 8 3 5 2}$ & 0,4468 \\
Y2.2 & 0,0908 & $-0,2616$ & 0,4009 & $\mathbf{0 , 8 3 2 8}$ & 0,4047 \\
Y2.3 & 0,4136 & $-0,2732$ & 0,2158 & $\mathbf{0 , 7 0 8 1}$ & 0,3795 \\
Y3.1 & 0,1676 & $-0,2411$ & 0,135 & 0,278 & $\mathbf{0 , 6 8 8 3}$ \\
Y3.2 & 0,1777 & $-0,3016$ & 0,3118 & 0,5197 & $\mathbf{0 , 9 2 5 2}$ \\
\hline
\end{tabular}

Koefisien Determinasi $\left(\mathrm{R}^{2}\right)$ digunakan untuk mengukur akurasi prediktif dari model yang diajukan. Dalam penelitian ini, nilai $R^{2}$ (Tabel 2) menunjukkan nilai $\mathrm{Y}_{1}: 0.0701, \mathrm{Y}_{2}: 0.2325$ dan $\mathrm{Y}_{3}$ : 0.2768. Hal ini menunjukkan bahwa variabel-variabel independen merupakan prediktor dari variabel dependennya. Akan tetapi mengingat nilai $\mathrm{R}^{2}$ yang rendah $(<0.5)$, maka variabelvariabel independen tersebut memiliki dampak yang relatif lemah pada variabel dependennya (Hair, Ringle, \& Sarstedt, 2011; Hair Jr et al., 2014). 
Dengan menggunakan bootstrapping, path coefficients digunakan untuk menggambarkan hubungan antar konstruk yang dihipotesiskan dalam model. (Hair et al., 2011). Uji hipotesis dilakukan dengan membandingkan critical $t$-value $(1,65$; significance level $=5 \%$ ) dengan $t$-statistic. Apabila nilai $t$-statistic $>1,65$ maka pengaruh antar variabel adalah signifikan. Hasil analisis sebagaimana pada Tabel 4 menunjukkan bahwa dari 7 hipotesis yang diajukan hanya satu hipotesis yang tidak terdukung $\left(\mathrm{H}_{5}\right)$.

Tabel 4 Path analysis and Hasil Hipotesis

\begin{tabular}{ccccc}
\hline Hipotesis & Path & $\begin{array}{c}\text { Original } \\
\text { Sample }(\mathrm{O})\end{array}$ & $\begin{array}{c}\text { T Statistics } \\
(\mid \text { O/STERR } \mid)\end{array}$ & Hasil \\
\hline $\mathrm{H}_{1}$ & Flow -> Adv. Att & 0,1488 & 2,2485 & Terdukung \\
$\mathrm{H}_{2}$ & Flow -> Brand Att & 0,1561 & 2,2327 & Terdukung \\
$\mathrm{H}_{3}$ & PK -> Adv. Att & $-0,1981$ & 2,8012 & Terdukung \\
$\mathrm{H}_{4}$ & PK -> Brand Att & $-0,1944$ & 3,0042 & Terdukung \\
$\mathrm{H}_{5}$ & Adv. Att - Brand Att & 0,3372 & 5,1189 & Terdukung \\
$\mathrm{H}_{6}$ & Adv. Att -> PI & 0,1037 & 1,281 & Tidak Terdukung \\
$\mathrm{H}_{7}$ & Brand Att -> PI & 0,4752 & 6,8265 & Terdukung \\
\hline
\end{tabular}

Sifat interaktif dari advergame dapat mendorong terjadinya flow, yaitu suatu keadaan dimana seseorang begitu terlibat dan tenggelam dalam aktifitas yang dilakukan (Csikszentmihalyi, 1990; Hoffman \& Novak, 2009). Hasil analisis pengaruh flow terhadap sikap atas advergame $\left(\mathrm{H}_{1}\right)$ mengkonfirmasi penelitian-penelitian sebelumnya yang mengemukakan bahwa flow dapat menghasilkan pengalaman dan evaluasi positif terhadap advergame dikarenakan pemain fokus pada permainan dan cenderung tidak menyadari pesan iklan yang ada. Hal ini menyebabkan pemain dapat menerima advergame tanpa menyadari bahwa advergame merupakan media iklan (Hernandez, 2011; Jin, 2011; Lang, 2000; Soebandhi et al., 2018; Waiguny et al., 2012). Hasil analisis pengaruh flow terhadap sikap anak-anak atas merek yang diiklankan dalam advergame juga menunjukkan pengaruh positif ( $\mathrm{H}_{2}$ terdukung). Hal ini sejalan dengan mere exposure effect (Zajonc, 1968) dan penelitian Waiguny (2013). Menurut kedua peneliti tersebut, paparan yang berulang dapat membentuk sikap positif terhadap merek yang diiklankan karena mereka semakin familier dengan merek tersebut.

Persuasion knowledge (PK) merupakan pengetahuan seseorang tentang motif dan taktik pengiklan. Pengetahuan ini akan membantu mereka mengidentifikasi bagaimana, kapan, dan mengapa pemasar mencoba mempengaruhi mereka (Friestad \& Wright, 1994; Panic et al., 2013). Semakin mereka tahu bahwa advergame merupakan media iklan, maka mereka akan bersikap skeptis dan memberikan evaluasi negatif baik terhadap advergame maupun merek yang diiklankan (Waiguny \& Terlutter, 2010). Terkait dengan Hipotesis 3 dan 4, penelitian ini sejalan dengan Persuasion Knowledge Model (Friestad \& Wright, 1994; Wright et al., 2005). Hasil analisis menunjukkan bahwa PK berpengaruh negatif terhadap advergame attitude $\left(\mathrm{H}_{3}\right)$ dan brand attitude $\left(\mathrm{H}_{4}\right)$ terbukti. PK dapat meningkat sejalan dengan meningkatnya paparan advergame (Buijzen, Van Reijmersdal, \& Owen, 2010; Janiszewski, 1993). Dalam penelitian ini, partisipan dapat memainkan game \pm 15 menit. Selama durasi tersebut, anak-anak dapat memainkan advergame berulangkali. Dengan memainkan advergame berulangkali, anak-anak semakin terbiasa dengan game yang dimainkan sehingga mereka memiliki kesempatan untuk memperhatikan produk yang diiklankan dan menyadari bahwa advergame adalah salah satu media pemasaran. Hal ini dapat membuat PK mereka menjadi aktif yang dapat berdampak pada evaluasi anak-anak terhadap advergame maupun produk yang terintegrasi dalam game (Boerman, Reijmersdal, \& Neijens, 2012). 
Sikap adalah evaluasi positif atau negatif individu terhadap suatu obyek (Mitchell \& Olson, 1981). Dalam advergame, produk yang diiklankan digunakan untuk memenangkan permainan. Mengaitkan merek dengan pengalaman yang menyenangkan dapat mempengaruhi sikap atas merek secara positif melalui mekanisme affect transfer (Nelson \& Waiguny, 2012; Reijmersdal, Rozendaal, \& Buijzen, 2012; Waiguny et al., 2011). Excitation transfer theory juga menjelaskan bahwa evaluasi atau perasaan yang disebabkan oleh suatu objek dapat ditransfer ke objek lain (Zillmann, 1971, 2007). Dalam kasus advergame, evaluasi positif dari permainan dapat ditransfer atau diteruskan ke merek yang diiklankan (Reijmersdal et al., 2012). Oleh karenanya, hasil penelitian ini mengkonfirmasi penelitian-penelitian sebelumnya ( $\mathrm{H}_{5}$ terdukung).

Advertising attitude merupakan kecenderungan untuk merespon secara positif atau negatif terhadap stimuli iklan selama paparan waktu tertentu (Lutz, 1985). Semakin baik evaluasi pemain terhadap advergame yang dimainkan semakin tinggi kecenderungan mereka untuk membeli produk yang diiklankan (Noor, Sreenivasan, \& Ismail, 2013). Akan tetapi hasil penelitian ini menunjukkan hasil yang berbeda ( $\mathrm{H}_{6}$ tidak terdukung). Advertising attitude tidak berdampak pada keinginan anak-anak untuk membeli produk yang dipromosikan dalam advergame. Hal ini dapat disebabkan karena advergame lebih menonjolkan hiburan daripada informasi produk, lebih interaktif dan immersive (Reijmersdal et al., 2012). Sehingga anakanak tidak akan menganggap advergame sebagai media iklan yang dapat mendorong mereka untuk melakukan pembelian (Kusumasondjaja, 2016; Soebandhi et al., 2018).

Brand attitude merupakan evaluasi merek berdasarkan pada kepercayaan pada atribut merek (Mitchell \& Olson, 1981). Pengalaman yang dirasakan saat memainkan advergame ini dapat membentuk perasaan suka atau tidak suka pada merek dalam game. Sikap positif ini penting karena dapat meningkatkan pembentukan niat perilaku (Ajzen, 1991, 2008). Hasil penelitian ini sejalan dengan penelitian Mallinckrodt dan Mizerski (2007) yang mengemukakan bahwa sikap positif anak-anak terhadap suatu merek dapat berdampak pada niat mereka untuk membeli produk tersebut $\left(\mathrm{H}_{7}\right.$ terdukung).

\section{SIMPULAN}

Advergame merupakan media yang unik untuk memasarkan produk pada anak-anak. Penekanan pada hiburan dan dapat dimainkan berulangkali dapat membuat anak-anak menerima paparan advergame lebih lama dibandingkan media pemasaran tradisional seperti televisi dan media cetak. Hal ini dapat menguntungkan pemasar karena advergame dapat meningkatkan engangement dan involvement anak-anak pada iklan dan merek yang selanjutnya dapat meningkatkan niat mereka untuk membeli produk yang diiklankan. Meskipun dalam penelitian ini dampak dari pengalaman flow dan persuasion knowledge terhadap sikap dan niat beli anak-anak relatif lemah, akan tetapi kebijakan yang mengatur tentang format baru ini tetap diperlukan dikarenakan anak-anak rentan terhadap pengaruh iklan.

Penelitian ini juga memiliki kelemahan. Pertama, penelitian ini menggunakan teknik convenience sampling yang didasarkan pada kemudahan untuk mendapatkan responden sehingga menyebabkan keterbatasan generalisasi temuan. Hal ini dikarenakan pengambilan data dilakukan di lingkungan sekolah sehingga diperlukan ijin dari pihak sekolah. Penelitian diwaktu yang akan datang dapat menggunakan teknik probability sampling agar dapat lebih mewakili populasi yang diteliti. Kedua, pada saat pengambilan data, anak-anak memainkan advergame dengan perangkat yang berbeda-beda. Hal ini dapat menghasilkan pengalaman yang berbeda dan dapat berdampak pada respon yang diberikan. Penelitian berikutnya dapat menggunakan perangkat yang sama sehingga diperoleh game experience yang serupa. Ketiga, penelitian ini hanya terbatas pada kelompok usia 10-12 tahun (kelas 5 SD). Penelitian 
selanjutnya dapat menggunakan kelompok usia yang berbeda untuk dapat mengeneralisasi hasil temuan ini.

\section{REFERENSI}

Ajzen, I. (1991). The Theory of Planned Behavior. Organizational Behavior and Human Decision Processes, 50(2), 179-211.

Ajzen, I. (2008). Consumer Attitudes and Behavior. In C. P. Haugtvedt, P. Herr \& F. Kardes (Eds.), Handbook of Consumer Psychology (pp. 525-548). New York: Lawrance Erlbaum Associates.

An, S., \& Stern, S. (2011). Mitigating the Effects of Advergames on Children. Journal of Advertising, 40(1), 43-56. doi: 10.2753/JOA0091-3367400103

Bahn, K. D. (1986). How and When do Brand Perceptions and Preferences First Form? A Cognitive Developmental Investigation. Journal of Consumer Research, 13(3), 382393.

Baker, W. E. (2010). Attitude Behavior Consistency. In J. N. Sheth \& N. Malhotra (Eds.), Wiley International Encyclopedia of Marketing: John Wiley \& Sons, Ltd.

Belch, G. E., \& Belch, M. A. (2018). Advertising \& Promotion: An Integrated Marketing Communications Perspective (11th ed.). New York, NY: McGraw-Hill Education.

Bellman, S., Kemp, A., Haddad, H., \& Varan, D. (2014). The Effectiveness of Advergames Compared to Television Commercials and Interactive Commercials Featuring Advergames. Computers in Human Behavior, 32, 276-283. doi: 10.1016/j.chb.2013.12.013

Boerman, S. C., Reijmersdal, E. A. v., \& Neijens, P. C. (2012). Sponsorship Disclosure: Effects of Duration on Persuasion Knowledge and Brand Responses. Journal of Communication, 62, 1047-1064. doi: 10.1111/j.1460-2466.2012.01677.x

Boerman, S. C., Reijmersdal, E. A. v., \& Neijens, P. C. (2013). Appreciation and Effects of Sponsorship Disclosure. In S. Rosengren, M. Dahlén \& S. Okazaki (Eds.), Advances in Advertising Research (Vol. IV) - The Changing Roles of Advertising (pp. 273-284). Sweden: Springer.

Bogost, I. (2007). Persuasive Games: The Expressive Power of Videogames. Cambridge: MIT Press.

Bousch, D. M., Friestad, M., \& Wright, P. (2009). Deception in the Marketplace: The Psychology of Deceptive Persuasion and Consumer Self Protection. New York: Routledge.

BPS. (2010). Penduduk Menurut Kelompok Umur dan Jenis Kelamin. diakses pada October 5 2016, dari https://sp2010.bps.go.id/index.php/site/tabel?searchtabel=Penduduk+Menurut+Kelompok+Umur+dan+Jenis+Kelamin\&tid=336\&searchwilayah=Indonesia\&wid=0000000000\&lang=id

BPS. (2011). Umur dan Jenis Kelamin Penduduk Indonesia: Hasil Sensus Penduduk 2010. Jakarta: Badan Pusat Statistik.

Breckler, S. J., \& Wiggins, E. C. (1989). Affect versus Evaluation in the Structure of Attitudes. Journal of Experimental Social Psychology, 25(3), 253-271. doi: 10.1016/00221031(89)90022-X

Brucks, M., Armstrong, G. M., \& Goldberg, M. E. (1998). Children's Use of Cognitive Defenses Against Television Advertising: A Cognitive Response Approach. Journal of Consumer Research, 14(4), 471-482.

Buckingham, D. (2000). After the Death of Childhood: Growing Up in the Age of Electronic Media. Cambridge: Polity Press. 
Buijzen, M., Van Reijmersdal, E. A., \& Owen, L. H. (2010). Introducing the PCMC Model: An Investigative Framework for Young People's Processing of Commercialized Media Content. Communication Theory, 20(4), 427-450. doi: 10.1111/j.14682885.2010.01370.x

Calvert, S. L. (2008). Children as Consumers: Advertising and Marketing. The Future of Children, 18(1), 205-234. doi: 10.1353/foc.0.0001

Campbell, M. C., \& Kirmani, A. (2000). Consumers' Use of Persuasion Knowledge: The Effects of Accessibility and Cognitive Capacity on Perceptions of an Influence Agent. Journal of Consumer Research, 27(1), 69-83.

Cauberghe, V., \& Pelsmacker, P. D. (2010). Advergames. Journal of Advertising, 39(1), 5-18. doi: 10.2753/JOA0091-3367390101

Chen, H. (2006). Flow on the Net-Detecting Web Users Positive Affects and Their Flow States. Computers in Human Behavior, 22, 221-233. doi: 10.1016/j.chb.2004.07.001

Csikszentmihalyi, M. (1990). Flow: The Psychology of Optimal Experience. New York: Harper \& Row.

Csikszentmihalyi, M., \& Lefevre, J. (1989). Optimal Experience in Work and Leisure. Journal of Personality and Social Psychology, 56(5), 815-822.

Evans, N. J., \& Park, D. (2015). Rethinking the Persuasion Knowledge Model: Schematic Antecedents and Associative Outcomes of Persuasion Knowledge Activation for Covert Advertising. Journal of Current Issues \& Research in Advertising, 36(2), 157176.

Friestad, M., \& Wright, P. (1994). The Persuasion Knowledge Model: How People Cope with Persuasion Attempts. Journal of Consumer Research, 21(1), 1-31.

Friestad, M., \& Wright, P. (1999). Everyday Persuasion Knowledge. Psychology \& Marketing, 16(2), 185-194.

Gross, M. L. (2010). Advergames and the Effects of Game-Product Congruity. Computers in Human Behavior, 26(6), 1259-1265. doi: 10.1016/j.chb.2010.03.034

Gunter, B. (2016). Kids and Branding in a Digital World. Manchester: Manchester University Press.

Gurău, C. (2008). The Influence of Advergames on Players' Behaviour: An Experimental Study. Electronic Markets, 18(2), 106-116. doi: 10.1080/10196780802044859

Hair, J. F., Hult, G. T. M., Ringle, C. M., \& Sarstedt, M. (2014). A Primer on Partial Least Squares Structural Equation Modeling (PLS-SEM). Thousand Oaks: Sage.

Hair, J. F., Ringle, C. M., \& Sarstedt, M. (2011). PLS-SEM: Indeed a Silver Bullet. Journal of Marketing Theory and Practice, 19(2), 139-152. doi: 10.2753/MTP1069-6679190202

Hair Jr, J. F., Sarstedt, M., Hopkins, L., \& G. Kuppelwieser, V. (2014). Partial Least Squares Structural Equation Modeling (PLS-SEM): An Emerging Tool in Business Research. European Business Review, 26(2), 106-121. doi: 10.1108/EBR-10-2013-0128

Hall, L. E., Hume, C., \& Tazzyman, S. (2016). Five Degrees of Happiness: Effective Smiley Face Likert Scales for Evaluating with Children. Paper presented at the IDC '16 Proceedings of the The 15th International Conference on Interaction Design and Children Manchester.

Hang, H., \& Auty, S. (2011). Children Playing Branded Video Games: The Impact of Interactivity on Product Placement Effectiveness. Journal of Consumer Psychology, 21(1), 65-72. doi: 10.1016/j.jcps.2010.09.004

Hendriyani, Hollander, E., D'Haenens, L., \& Beentjes, J. W. J. (2012). Children's media use in Indonesia. Asian Journal of Communication, 22(3), 304-319. 
Hernandez, M. D. (2008). Determinants of Children's Attitudes towards "Advergames": The Case of Mexico. Young Consumers, 9(2), 112-120. doi: 10.1108/17473610810879684

Hernandez, M. D. (2011). A Model of Flow Experience as Determinant of Positive Attitudes Toward Online Advergames. Journal of Promotion Management, 17(3), 315-326. doi: 10.1080/10496491.2011.596761

Hernandez, M. D., Chapa, S., Minor, M. S., Maldonado, C., \& Barranzuela, F. (2004). Hispanic Attitudes toward Advergames: A Proposed Model of their Antecedents. Journal of Interactive Advertising, 5(1), 74-83.

Hoffman, D. L., \& Novak, T. P. (2009). Flow Online: Lessons Learned and Future Prospects. Journal of Interactive Marketing, 23(1), 23-34. doi: 10.1016/j.intmar.2008.10.003

Hoyer, W. D., MacInnis, D. J., \& Pieters, R. (2013). Consumer Behavior (6th ed.). SouthWestern: Cengage Learning.

Janiszewski, C. (1993). Preattentive Mere Exposure Effects. Journal of Consumer Research, 20(3), 376-392. doi: 10.1086/209356

Jin, S.-A. A. (2011). "I Feel Present. Therefore, I Experience Flow:"A Structural Equation Modeling Approach to Flow and Presence in Video Games. Journal of Broadcasting \& Electronic Media, 55(1), 114-136.

John, D. R. (1999). Consumer Socialization of Children: A Retrospective Look at Twenty Five Years of Research. Journal of Consumer Research, 26(3), 183-213.

Kaneva, N. (2007). Viral Marketing. In J. J. Arnett (Ed.), Encyclopedia of Children, Adolescents, and the Media (Vol. 2, pp. 867-868). Thousand Oaks, California: Sage.

Kardes, F., Cronley, M., \& Cline, T. (2011). Consumer Behavior. Mason, OH: Cengage Learning.

Kemdikbud. (2018). Data Referensi Pendidikan dan Kebudayaan. diakses pada March 82018 , dari http://referensi.data.kemdikbud.go.id/index.php

Kominfo. (2013). Jumlah pengguna internet berdasarkan kota di Indonesia tahun 2013. diakses pada $\quad$ March $\quad 2018, \quad$ dari https://statistik.kominfo.go.id/site/data?idtree=326\&iddoc $=1186$

Kusumasondjaja, S. (2016). Respon Konsumen pada Mobile Advergames: Intrusiveness dan Irritation. Jurnal Manajemen Teknologi, 15(3), 206-223. doi: 10.12695/jmt.2016.15.3.1

Lang, A. (2000). The Limited Capacity Model of Mediated Message Processing. Journal of Communication, 50(1), 46-70. doi: 10.1111/j.1460-2466.2000.tb02833.x

Lu, A. S., Baranowski, T., Thompson, D., \& Buday, R. (2012). Story Immersion of Videogames for Youth Health Promotion: A Review of Literature. Games for Helath Journal: Research, Development, and Clinical Applications, 1(3). doi: 10.1089/g4h.2011.0012

Lutz, R. J. (1985). Affective and Cognitive Antecedents of Attitude Toward the Ad: A Conceptual Framework. In L. F. Alwitt \& A. A. Mitchell (Eds.), Psychological Processes and Advertising Effects: Theory, Research and Application (pp. 45-63). Hillsdale, NJ: Erlbaum.

Mackay, T., Ewing, M., Newton, F., \& Windisch, L. (2009). The Effect of Product Placement in Computer Games on Brand Attitude and Recall. International Journal of Advertising: The Review of Marketing Communications, 28(3), 423-438. doi: $10.2501 / \mathrm{S} 0265048709200680$

Mallinckrodt, V., \& Mizerski, D. (2007). The Effects of Playing an Advergame on Young Children's Perceptions, Preferences, and Requests. Journal of Advertising, 36(2), 87100. doi: 10.2753/JOA0091-3367360206 
Mau, G., Silberer, G., \& Constien, C. (2008). Communicating Brands Playfully. International Journal of Advertising, 27(5), 827-851. doi: 10.2501/S0265048708080293

Mitchell, A. A., \& Olson, J. C. (1981). Are Product Attribute Beliefs the Only Mediator of Advertising Effects on Brand Attitude? Journal of Marketing Research, 18(3), 318332.

Moore, E. S., \& Rideout, V. J. (2007). The Online Marketing of Food to Children: Is It Just Fun and Games? Journal of Public Policy \& Marketing, 26(2), 202-220. doi: 10.1509/jppm.26.2.202

Nakamura, J., \& Csikszentmihalyi, M. (2002). The Concept of Flow. In C. R. Snyder \& S. J. Lopez (Eds.), Handbook of Positive Psychology (pp. 89-105). New York: Oxford University Press.

Nelson, M. R., \& Waiguny, M. K. J. (2012). Psychological Processing of In-Game Advertising and Advergaming: Branded Entertainment or Entertaining Persuasion? In L. J. Shrum (Ed.), The Psychology of Entertainment Media: Blurring the Lines Between Entertainment and Persuasion (2nd ed., pp. 93-144). Mahwah, NJ: Taylor and Francis.

Nicovich, S. G. (2005). The Effect of Involvement on Ad Judgment in a Video Game Environment. Journal of Interactive Advertising, 6(1), 29-39. doi: 10.1080/15252019.2005.10722105

Noor, M. N. M., Sreenivasan, J., \& Ismail, H. (2013). Malaysian Consumers' Attitude towards Mobile Advertising and its Impact on Purchase Intention - A Structural Equation Modeling Approach. International Journal of Economics and Statistics, 3(1), 148-155.

Obringer, L. A. (2007). How Advergaming Works. diakses pada 26 September 2016, dari http://money.howstuffworks.com/advergaming.htm/printable

Panic, K., Cauberghe, V., \& De Pelsmacker, P. (2013). Comparing TV Ads and Advergames Targeting Children: The Impact of Persuasion Knowledge on Behavioral Responses. Journal of Advertising, 42(2-3), 264-273. doi: 10.1080/00913367.2013.774605

Phelps, J. E., \& Hoy, M. G. (1996). The Aad-Ab-PI Relationship in Children: The Impact of Brand Familiarity and Measurement Timing. Psychology \& Marketing, 13(1), 77-105.

PwC. (2017). Perspectives from the Global Entertainment and Media Outlook 2017-2021 (Vol. 2017).

Redwing. (2014). Technology is Changing the Face of Advertising in Indonesia. diakses pada 15 Maret 2016, dari http://redwing-asia.com/analysis-posts/technology-changing-faceadvertising-indonesia/

Reijmersdal, E. A. v., Rozendaal, E., \& Buijzen, M. (2012). Effects of Prominence, Involvement, and Persuasion Knowledge on Children's Cognitive and Affective Responses to Advergames. Journal of Interactive Marketing, 26, 33-42. doi: 10.1016/j.intmar.2011.04.005

Reynolds-keefer, L., \& Johnson, R. (2011). Is a Picture is Worth a Thousand Words? Creating Effective Questionnaires with Pictures. Practical Assessment, Research \& Evaluation, 16(8), 1-7.

Rideout, V. J., Foehr, U. G., \& Roberts, D. F. (2010). Generation M2: Media in the Lives of 8to 18-Year-Olds. Menlo Park: CA.

Robertson, T. S., \& Rossiter, J. R. (1974). Children and Commercial Persuasion: An Attribution Theory Analysis. Journal of Consumer Research, 1(1), 13-20.

Roedder, D. L., Sternthal, B., \& Calder, B. J. (1983). Attitude-Behavior Consistency in Children's Responses to Television Advertising. Journal of Marketing Research, 20(4), 337-349. 
Rozendaal, E., Buijzen, M., \& Valkenburg, P. (2009). Do Children's Cognitive Advertising Defenses Reduce their Desire for Advertised Products? . Communications, 34, 287303. doi: 10.1515/COMM.2009.018

Rozendaal, E., Buijzen, M., \& Valkenburg, P. (2010). Comparing Children's and Adults' Cognitive Advertising Competences in the Netherlands. Journal of Children and Media, 4(1), 77-89. doi: 10.1080/17482790903407333

Rozendaal, E., Lapierre, M. A., Reijmersdal, E. A. v., \& Buijzen, M. (2011). Reconsidering Advertising Literacy as a Defense Against Advertising Effects. Media Psychology, 14(4), 333-354,. doi: 10.1080/15213269.2011.620540

Rozendaal, E., Slot, N., Reijmersdal, E. A. v., \& Buijzen, M. (2013). Children's Responses to Advertising in Social Games. Journal of Advertising, 42(2-3), 142-154. doi: $10.1080 / 00913367.2013 .774588$

Sherry, J. L. (2004). Flow and Media Enjoyment. Communication Theory, 14(4), 328-347.

Soebandhi, S., Hartini, S., \& Gunawan, S. (2018). Children and Advergame: The Role of Presence, Flow, and Persuasion Knowledge. International Journal of Electronic Business, 14(4), 293-308. doi: 10.1504/IJEB.2018.098126

Soebandhi, S., Hartini, S., \& Gunawan, S. (2020). Engaging Young Consumers with Advergames: The effect of Presence and Flow Experience. In R. Hurriyati, B. Tjahjono, I. Yamamoto, A. Rahayu, A. G. Abdullah \& A. A. Danuwijaya (Eds.), Advances in Business, Management and Entrepreneurship (pp. 97-101). London: Taylor \& Francis Group.

Solomon, M. R. (2018). Consumer Behavior: Buying, Having, and Being. Global Edition (12th ed.): Pearson.

Steffen, C., Mau, G., \& Schramm-klein, H. (2013). Who Is the Loser When I Lose the Game? Does Losing an Advergame Have a Negative Impact on the Perception of the Brand? Journal of Advertising, 42(2-3), 183-195. doi: 10.1080/00913367.2013.774598

Terlutter, R., \& Capella, M. L. (2013). The Gamification of Advertising: Analysis and Research Directions of In-Game Advertising, Advergames, and Advertising in Social Network Games. Journal of Advertising, 42(2-3), 95-112. doi: 10.1080/00913367.2013.774610

Vanwesenbeeck, I., Ponnet, K., \& Walrave, M. (2016). Go with the flow: How children's persuasion knowledge is associated with their state of flow and emotions during advergame play. Journal of Consumer Behaviour, 47(1), 38-47. doi: 10.1002/cb

Verhellen, Y., Oates, C., Pelsmacker, P. D., \& Dens, N. (2014). Children's Responses to Traditional Versus Hybrid Advertising Formats: The Moderating Role of Persuasion Knowledge. Journal of Consumer Policy, 37(2), 235-255. doi: 10.1007/s10603-0149257-1

Vermeir, I., Kazakova, S., Tessitore, T., Cauberghe, V., \& Slabbinck, H. (2014). Impact of Flow on Recognition of and Attitudes towards In-Game Brand Placements. International Journal of Advertising, 33(4), 785-810. doi: 10.2501/IJA-33-4-785-810

Voges, K., Pope, N., \& Brown, M. (2003). Buying or Browsing? An exploration of Shopping Orientations and Online Purchase Intention. European Journal of Marketing, 37(11/12), 1666-1684. doi: 10.1108/03090560310495401

Waiguny, M. K. J. (2013). Investigating the Entertainment-Persuasion Link: Can Educational Games Influence Attitudes Toward Products? In S. Rosengren, M. Dahlén \& S. Okazaki (Eds.), Advances in Advertising Research (Vol. IV) - The Changing Roles of Advertising (pp. 173-186): Springer Fachmedien Wiesbaden. 
Waiguny, M. K. J., Nelson, M. R., \& Terlutter, R. (2012). Entertainment Matters! The Relationship between Challenge and Persuasiveness of an Advergame for Children. Journal of Marketing Communications, 18(1), 69-89.

Waiguny, M. K. J., \& Terlutter, R. (2010). Entertainment in Advergames and its Influence on Brand-Related Outcomes for Children. In R. Terlutter, S. Diehl \& S. Okazaki (Eds.), Advances in Advertising Research (Vol. 1) (pp. 171-186). Germany: Gabler.

Waiguny, M. K. J., Terlutter, R., \& Zaglia, M. E. (2011). The Influence of Advergames on Consumers' Attitudes and Behaviour: An Empirical Study among Young Consumers. International Journal of Entrepreneurial Venturing, 3(3), 231-247. doi: 10.1504/IJEV.2011.041273

Wright, P., Friestad, M., \& Boush, D. M. (2005). The Development of Marketplace Persuasion Knowledge in Children, Adolescents, and Young Adults. Journal of Public Policy \& Marketing, 24(2), 222-233.

Youn, S., \& Mira, L. (2012). In-Game Advertising and Advergames: A Review of the Past Decade's Research. In S. Rodgers \& E. Thorson (Eds.), Advertising Theory (pp. 388401). New York: Routledge.

Zajonc, R. B. (1968). Attitudinal Effects of Mere Exposure. Journal of Personality and Social Psychology, Monograph Supplement, 9(2), 1-27.

Zillmann, D. (1971). Excitation Transfer in Communication-mediated Aggressive Behavior. Journal of Experimental Social Psychology, 7, 419-434. doi: 10.1016/00221031(71)90075-8

Zillmann, D. (2007). Arousal Theories. In J. J. Arnett (Ed.), Encyclopedia of Children, Adolescents, and the Media (pp. 101-104). Thousand Oaks: Sage Publications. 